\title{
HIGH PREVALENCE OF MALARIA INFECTION IN AMAZONAS STATE, VENEZUELA
}

\author{
Hectorina RODULFO(1,2), Marcos DE DONATO(1), Isaurea QUIJADA(1) \& Ada PEÑA(3)
}

\begin{abstract}
SUMMARY
This study was carried out to determine the incidence of malaria in an endemic region of Amazonas State, Venezuela. For this, 200 random samples were collected from symptomatic and asymptomatic individuals from San Fernando de Atabapo and Santa Barbara. Epidemiological factors were related to malaria infection, which was diagnosed by microscopy observation and amplification of the $18 \mathrm{~S}$ rDNA sequence by PCR. Malaria prevalence in these populations was $28.5 \%$, whilst $P$. vivax and $P$. falciparum prevalences were 12 and $17 \%$, respectively. No infection by P. malariae was found. A mixed infection was found on an asymptomatic individual. Prevalence patterns differed between age groups depending on the Plasmodium species. We found that $34.8 \%$ of the $P$. vivax and $15.2 \%$ of the $P$. falciparum infections were asymptomatic. The use of nets was helpful to prevent $P$. vivax infection, but did not protect against $P$. falciparum infection. The results suggest the presence of more than one mosquito vector in the area, displaying a differential pattern of infection for each Plasmodium species. There appear to be risk factors associated with malaria infections in some individuals. The population based approach and PCR diagnosis improved the accuracy of the statistical analysis in the study.
\end{abstract}

KEYWORDS: Epidemiology; Malaria; PCR; P. falciparum; P. vivax.

\section{INTRODUCTION}

Malaria is the most prevalent human parasitosis world-wide, and in the last seven years in Venezuela, 202,800 new malaria infections have been recorded, originating mainly in Bolivar, Sucre and Amazonas States. During 2004 and 2005, 46,244 and 45,328 new malaria cases were registered in Venezuela, respectively, of which $93.1 \%$ were from these three states ${ }^{13}$. These are among the highest numbers of cases in this country since 1936. Amazonas State is one of the most important endemic areas of the country, with an annual parasitological incidence (API, number of cases per 1000 inhabitants) of 102.2 for 2004, which was the highest in the country, followed by Bolivar, Delta Amacuro and Sucre States with API's of 19.2, 12.5 and 5.5, respectively. Atabapo is the municipality with the third highest API in Amazonas and the sixth in Venezuela with 111 cases per 1000 inhabitants.

The Amazonian region is characterized as a tropical rain forest with high precipitation, and high temperature and humidity throughout the year. This region is inhabited mainly by indigenous people, which have nomadic habits and rudimentary housing, making the application of control measures with insecticides and antimalarial drugs more difficult. Malaria infections are produced by $P$. falciparum, $P$. vivax and occasionally $P$. malariae ${ }^{1}$. The main vector reported for this area is $A$. darlingi, which shows relatively good tolerance but high irritability to the insecticides used in this region. This species has exophilic habits favored by the selvatic environment ${ }^{30}$.

Malaria epidemiology is affected by the interaction among human (e.g. age, immunity, nutritional state) climatic (mainly temperature and humidity) and biological factors (vectors, parasites) which contribute to the establishment of the infection in endemic areas ${ }^{24,37}$. The effects of each of these factors must be elucidated in order to implement effective control measures to reduce the prevalence of malaria infection in endemic areas.

Most recent epidemiological studies in endemic areas of malaria have been carried out with symptomatic patients and attempt to correlate the infection with epidemiological factors ${ }^{5,69}$. The use of more precise diagnostic methods in population based studies, allowing for screening for both symptomatic and asymptomatic individuals taken at random from the population, could produce a better understanding of the multiple epidemiological factors affecting malaria infection. We carried out an epidemiological study using molecular diagnostic techniques to detect the Plasmodium species present in an endemic area of Amazonas State, Venezuela.

\section{MATERIALS AND METHODS}

Before carrying out this study, participants were given all the relevant information and only those individual who signed a written 
consent were incorporated, according to the protocol of the Institute of Investigations in Biomedicine and Applied Sciences (IIBCA), Universidad de Oriente, and following the guidelines of the Bioethics and Biosecurity code of the Science and Technology Ministry (MCT) and the National Fund of Science and Technology (FONACIT) of Venezuela ${ }^{11}$. The participation of children was authorized by their parents or legal representatives.

Blood samples were taken from a total of 200 individuals chosen at random from the San Fernando de Atabapo and Santa Barbara areas (Fig. 1), Atabapo municipality, in January of 2004, with and without symptoms, from both sexes and all age groups. These are rural populations with about 6000 inhabitants, composed mainly by indigenous people belonging to the Piaroa ethnia, whose main economical activities are agriculture and fishing, and the main means of transport is by boat along the Orinoco river (Instituto Nacional de Estadistica: http://www.ine.gov.ve). Sample size was calculated according to ROSNER (2000) taking values of $\alpha=0.05, \mathrm{n}=6000$, precision of $4 \%$ and an estimated prevalence of $10 \%$, according to previous studies ${ }^{21,29,38}$. To best select the individuals at random, we randomly selected houses from each area, and took samples from up to three individuals per house from different age groups and gender, and with or without malaria symptoms.

An epidemiological cross-sectional study was carried out with all participants, along with the members of his/her immediate family, using

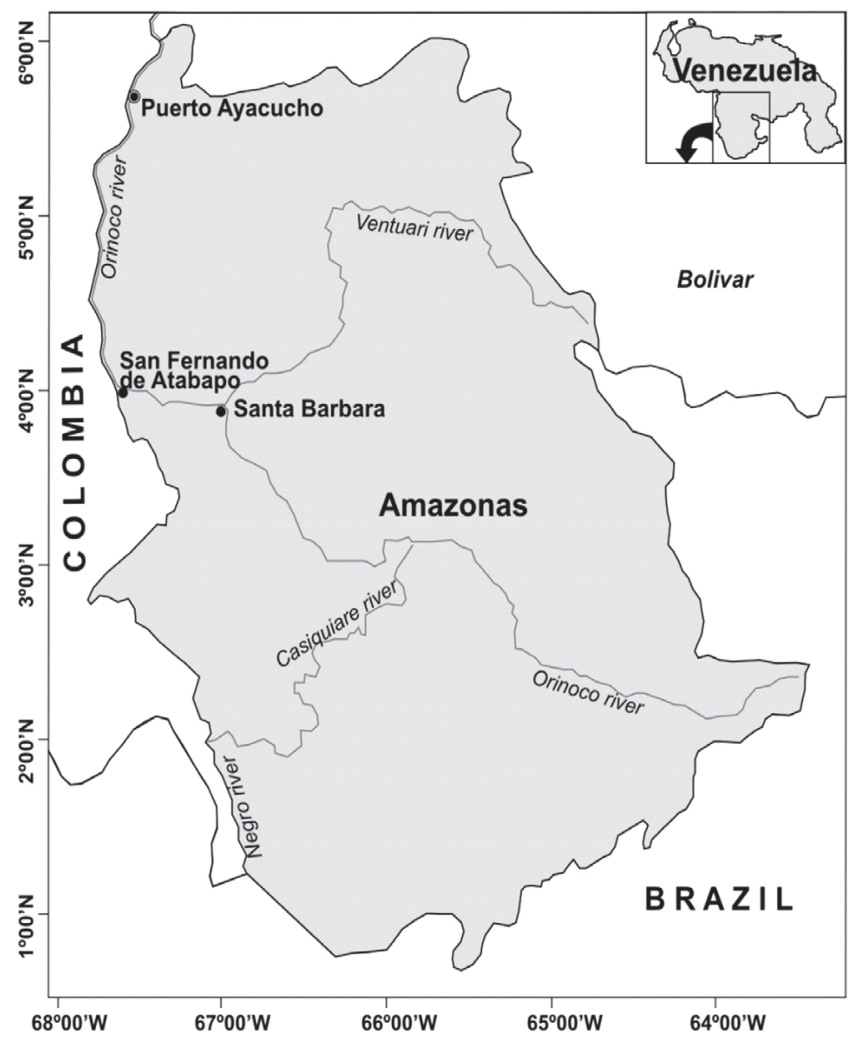

Fig. 1 - Map of Amazonas State showing the rural populations from which the samples were taken: San Fernando de Atabapo and Santa Barbara. a structured questionnaire, to obtain the epidemiological information needed, and recording among other things, personal characteristics such as age, sex, occupation, previous malaria infections, symptoms and knowledge of the disease, as well as epidemiological variables from the environment that could facilitate the transmission and maintenance of the infection in endemic areas.

Microscopic diagnosis consisted in the observation of the Plasmodium parasite in the blood of studied individuals seen under a microscope. Thick and thin smears were prepared from blood drops taken from one of the ear lobes of each individual, and immediately stained with Giemsa for 15 minutes. The slides were examined under a light microscope and the results were scored after the observation of 100 fields at $100 \mathrm{X}$ magnification ${ }^{21}$. The diagnosis of the slides was carried out by a trained microscopist from the malaria control services located in the area. All individuals were immediately told the results of the microscopy diagnosis, and those who were diagnosed positive for any Plasmodium species received the corresponding treatment.

For the molecular diagnosis, $5 \mathrm{~mL}$ blood samples were drawn by venous puncture, taking all the biosecurity precautions, stored in sterile, plastic tubes mixed with EDTA as an anticoagulant and kept cold (below $0{ }^{\circ} \mathrm{C}$ ) until their arrival at the laboratory, (under 24 hours), where they were stored at $-80{ }^{\circ} \mathrm{C}$ until use. DNA was purified from whole blood using the Wizard Genomic DNA extraction kit (Promega Corp., Madison, WI, USA) according to the directions of the manufacturer. We used a total of $150 \mu \mathrm{L}$ of blood for the extraction and we resuspended the isolated genomic DNA in $50 \mu \mathrm{L}$ of $1 \mathrm{X}$ Tris-HCl-EDTA buffer.

Amplification was carried out by polymerase chain reaction (PCR) in $25 \mu \mathrm{L}$-volume using Taq polymerase buffer $(10 \mathrm{mM}$ Tris- $\mathrm{HCl}, \mathrm{pH}$ 9.0, $50 \mathrm{mM} \mathrm{KCl}, 0.1 \%$ Triton X-100), $200 \mu \mathrm{M}$ of each dNTP, $0.75 \mathrm{U}$ of Taq polymerase (Promega Corp., Madison, WI, USA), either $1 \mathrm{mM}$ $\mathrm{MgCl}_{2}$ (for $P$. vivax) or $3 \mathrm{mM} \mathrm{MgCl}$ (for P. falciparum and P. malariae) and $2 \mu \mathrm{L}$ of diluted DNA (about $100 \mathrm{ng}$ ). PCR was performed individually for each species using previously published oligonucleotides $^{39}$ at a concentration of $175 \mathrm{nM}$. The program used for the amplification included a modification of the original, running the first 10 cycles with one step of extension at $94{ }^{\circ} \mathrm{C}$ for one min, one step of annealing at $54{ }^{\circ} \mathrm{C}$ for two min and one step of polymerization at $72{ }^{\circ} \mathrm{C}$ for two min. The next 35 cycles were run with extension at $94{ }^{\circ} \mathrm{C}$ for $45 \mathrm{~s}$, annealing at $56{ }^{\circ} \mathrm{C}$ for $90 \mathrm{~s}$ and polymerization at $72{ }^{\circ} \mathrm{C}$ for one min. A final extension at $72{ }^{\circ} \mathrm{C}$ for $10 \mathrm{~min}$ was carried out. This modification improved the intensity of the signal while decreasing the background noise of the amplification.

The association of the epidemiological factors with malaria infection was evaluated using the Chi-squared test and logistic regression, included in the software package SPSS V.10. Prevalence ratios (PR) and their confidence intervals were calculated, according to KAHN \& TEMPOS (1989), instead of prevalence odds ratio (POR) since PR is a conservative, consistent, and interpretable ratio relative to the incidence rate ratio (IRR) and should be used in preference to the $\mathrm{POR}^{41}$. For the purpose of this study, we considered symptomatic individuals as those who showed any symptoms related to malaria (body temperature of $38^{\circ} \mathrm{C}$ or higher, and/or persistent headache, general pain, or weakness) at the moment of the collection of the sample of blood or declared by the patient or parent, and asymptomatic individuals 
as those who did not show or declare any symptoms either at the time when the sample of blood was withdraw or at the time of treatment, when confirmed by PCR, two weeks later. Those who did show symptoms before treatment were considered symptomatic.

\section{RESULTS}

We detected 57 cases of malaria infection among the 200 samples evaluated, 23 of which were caused by $P$. vivax $(11.5 \%), 33$ by $P$. falciparum (16.5\%) and one caused by both species $(0.5 \%)$. No infection caused by $P$. malariae was detected by microscopy or PCR. Male prevalence was slightly higher than for females; for $P$. vivax (13.3\% vs $10.8 \%)$, P. falciparum $(19.4 \%$ vs $14.7 \%)$ and malaria in general $(31.6 \%$ vs $25.5 \%)$, but the differences were not statistically significant.

The epidemiological evaluation of the data showed that the age of the individuals was statistically associated with malaria infection $\left(\chi^{2}\right.$ $=14.76, \mathrm{p}<0.05)$, with the highest malaria prevalences in individuals younger than 10 years old (Fig. 2a). When analyzing the prevalences of infection of the age groups, for each Plasmodium species, we found that $P$. vivax infection was not associated with age $\left(\chi^{2}=8.19, \mathrm{p}>\right.$ $0.05)$, but $P$. falciparum was associated $\left(\chi^{2}=11.57, \mathrm{p}<0.05\right)$, showing decreasing rates of infection with age (Fig. 2a), while $P$. vivax infection showed no age-specific pattern.

The clinical analysis of the Plasmodium infected individuals demonstrated that $24.6 \%(14 / 57)$ of the individuals were asymptomatic (Table 1$)$, of which eight cases $(34.8 \%)$ were infected by $P$. vivax, and $5(15.2 \%)$ by $P$. falciparum. The difference in the number of asymptomatic individuals infected depending on the Plasmodium species was statistically significant $\left(\chi^{2}=19.34 ; \mathrm{p}<0.01\right)$. The individual with the mixed infection was also asymptomatic (Table 1$)$.

Table 1

Number of symptomatic and asymptomatic individuals infected with Plasmodium in the population studied

\begin{tabular}{lccc}
\hline Species & Symptomatic & Asymptomatic & Total \\
\hline$P$. vivax & 15 & 8 & 23 \\
$P$. falciparum & 28 & 5 & 33 \\
Mixed infection & 0 & 1 & 1 \\
Malaria infection & 43 & 14 & 57 \\
Not infected & 24 & 119 & 143 \\
Total & 67 & 133 & 200 \\
\hline
\end{tabular}

There was no relationship between symptoms and the number of malaria episodes

On the other hand, there was a relationship between age and symptoms found in P. vivax infected individuals, whereby $100 \%$ of the children under 10 years old had fever, but only $50 \%$ of the individuals 10 years or older had fever (Fig. 2b). For P. falciparum infections, fever was detected in $57.1 \%$ of the children under 10 years old, and in $79.4 \%$ of the individuals 10 years or older (Fig. 2b).

Overall, fever was found in $54.7 \%$ of the individuals with a malaria infection and only two infected individuals with headaches did not suffer fever. Due to the high statistical association of fever with malaria
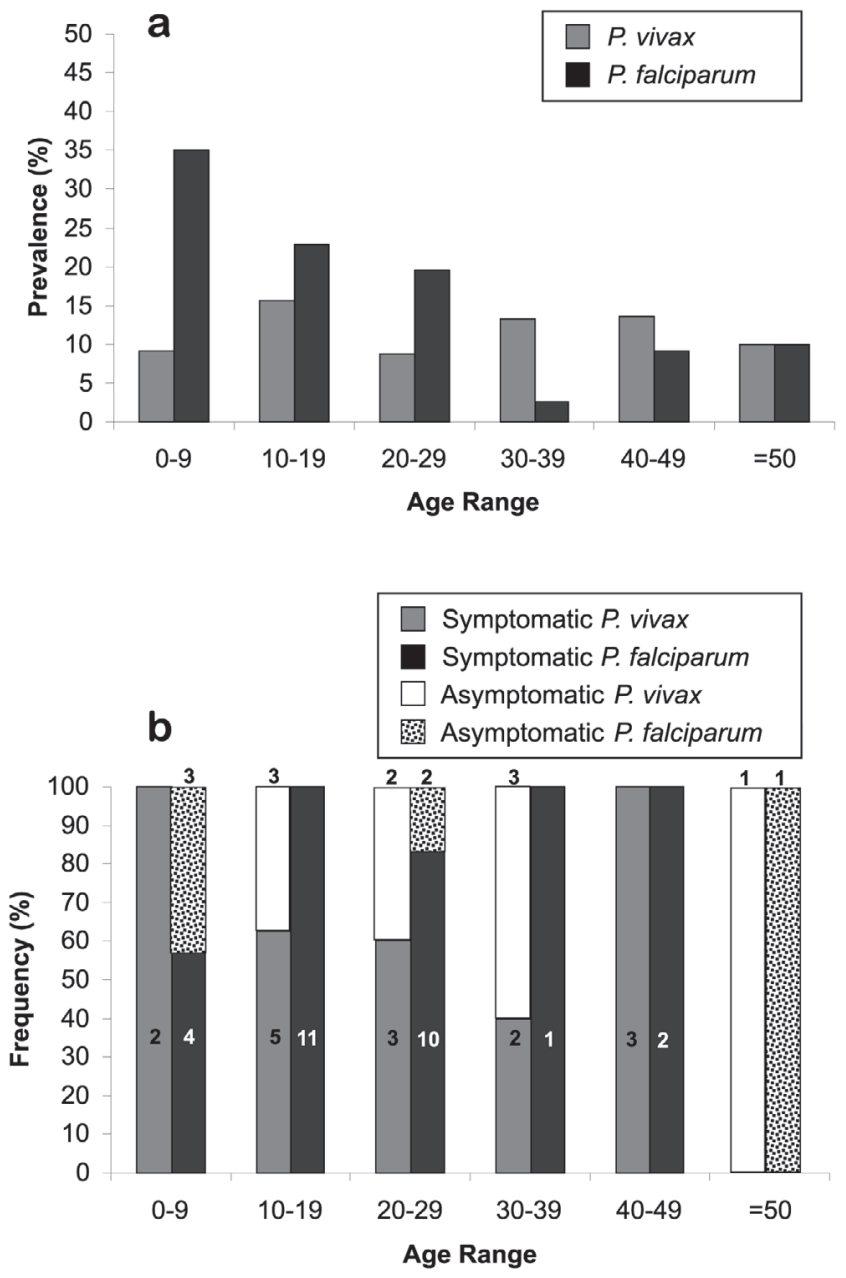

Fig. 2 - Prevalence of species-specific malaria infection (a) and species-specific relative frequencies of symptomatic vs. asymptomatic infections (b), for each age group of the individuals studied. Numbers in (b) represent number of cases. The infected individual with an age $\geq 50$ for both species represents the one individual with a mixed infection. Of the symptomatic individuals, all but one case of $P$. falciparum and one case of $P$. vivax, both from the 20-29 age group, had no fever during the sampling nor was referred by the patients.

$\left(\chi^{2}=20.71, \mathrm{p}<0.01\right)$, this symptom could be used for screening symptomatic infections, with a prevalence ratio (PR) indicating that individuals with fever were $5.36 \pm 0.67$ times more likely to be infected by Plasmodium than with any other symptom or without any symptom. However, the number of asymptomatic infections (14/57) indicates that general population screening methods are needed in order to decrease the high incidence of malaria in this endemic area.

Most individuals (89.0\%) used mosquito nets when sleeping, including adults and children of both sexes. The use of nets was negatively associated with $P$. vivax infection $\left(\chi^{2}=5.46, \mathrm{p}<0.05\right)$, with an infection frequency of $54.6 \%$ for those who did not use nets and $6.7 \%$ for those who did use them (Fig 3a). Thus, people who did not use mosquito nets were a $7.86 \pm 0.91(\mathrm{PR})$ times more likely to be infected by $P$. vivax. Infection by $P$. falciparum, however, was not statistically associated with the use of nets. 

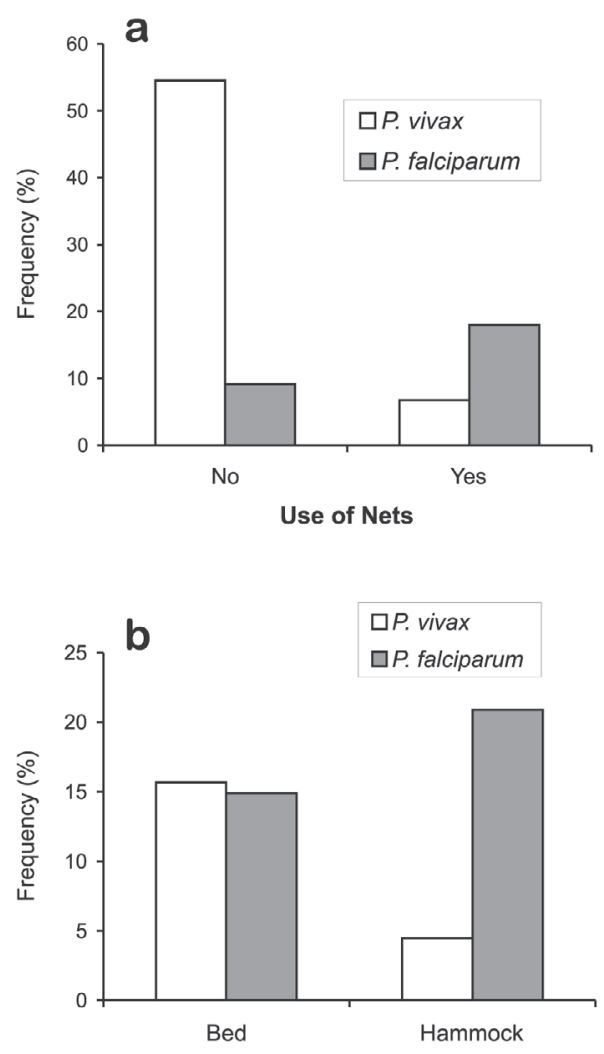

Fig. 3 - Frequency of malaria infection with and without the use of nets (a) and according to the type of sleeping accommodation (b) used by the studied individuals.

People from San Fernando de Atabapo and Santa Barbara use beds more frequently for sleeping $(66.5 \%)$ than hammocks. Infection by both species of Plasmodium was similar in individuals sleeping in beds, whilst those sleeping in hammocks had a much lower frequency of $P$. vivax infection (Fig. 3b), $\left(\chi^{2}=5.40, \mathrm{p}<0.05\right)$, whereas no association was found for P. falciparum infections (Fig. 3b). However, this factor was also associated with the use of nets $\left(\chi^{2}=\right.$ $6.71, \mathrm{p}<0.05)$, where most individuals who did not use mosquito nets slept on beds, thus showing an interaction between these two factors and $P$. vivax infection.

The number of previous malaria episodes of the individuals studied showed a positive association $\left(\chi^{2}=15.42, \mathrm{p}<0.01\right)$ with current malaria infection (Fig. 4). Most of the infected individuals (50\%) had had two or more previous malaria infections, whilst fewer uninfected individuals (26.6\%) had had two or more previous infections. The number of previous malaria episodes was not correlated with the age of the individuals $\left(\mathrm{R}^{2}=0.054, \mathrm{CC}=0.233, \mathrm{p}>0.05\right)$, thus the association between the previous episodes with current infection could not be explained by this factor. The prevalence ratio of $1.47 \pm 0.25$ showed a higher risk of malaria infection for those individuals with more than one previous infection. However, there was no association between the number of episodes and the development of symptoms in the infected individuals $\left(\chi^{2}=0.27, \mathrm{p}>0.05\right)$.

Other epidemiological factors studied such as the characteristics of the houses and surrounding environment were not statistically

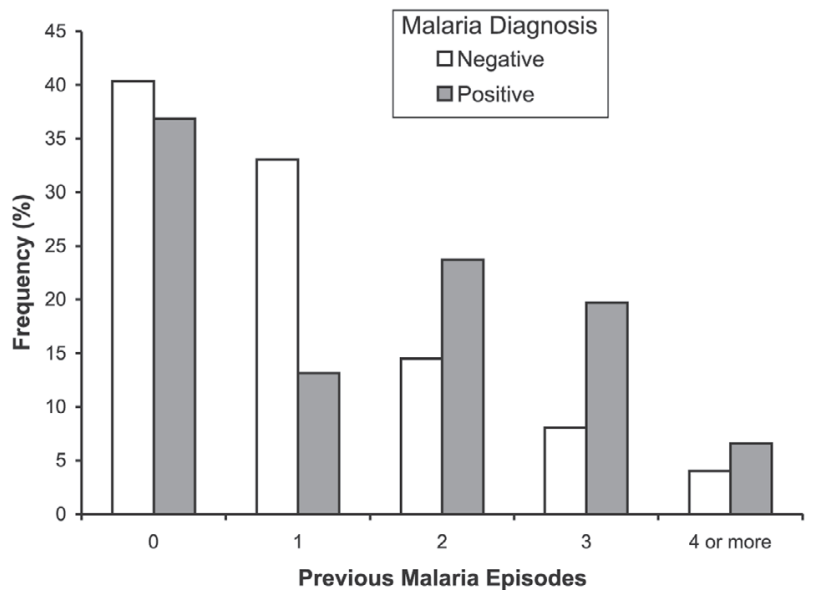

Fig. 4 - Frequency of patients with different numbers of malaria episodes according to their current infection status, in the population studied.

associated with malaria infection. The inhabitants' knowledge of malaria, its cause, treatment and prevention was also not associated with infection, and neither were other behavioral or cultural aspects. It is noticeable that in spite of the fact that these individuals live in an endemic area, their knowledge of malaria is poor and mostly limited to the association of the disease with the mosquito vector.

\section{DISCUSSION}

This study demonstrated that San Fernando de Atabapo and Santa Barbara represent an endemic area of relatively high malaria transmission. The malaria prevalence value found here $(28.5 \%)$ was somewhat higher than that reported by the Direction of Epidemiologic Vigilance, Ministry of Health for the year 2004. However, Amazonas State showed the highest annual parasitological index, API, (102.2 cases/1000 inhabitants) for that year, and more specifically, the municipality of Atabapo, had the third highest API (111) in the state, only comparable with hyperendemic areas for malaria. This malaria prevalence was intermediate from the prevalences reported for Yanomami communities living in the high Orinoco basin in Venezuela, and communities from the high Mucajaí basin in Brazil ${ }^{22}$, but there the most prevalent parasite was $P$. vivax, different from our study.

SA et al. (2005) after studying 1933 malaria cases found no association with age or gender and malaria infection, but there was an association between infection and the cultural activities of the people outside their homes in peak hours of vector activity, which facilitated exposition to infection ${ }^{36}$. In our study we did not find any statistically significant association between malaria infection and epidemiological factors such as gender and occupation, demonstrating that they are not risk factors in these populations, even though occupation has been related to malaria incidence in other populations, due to the increase of exposition to the vector of people with certain activities ${ }^{32}$. In Rondonia State, Brazil, transmission appears to be related predominantely to occupation and to extra-domiciliary infection ${ }^{10}$. In a recent overview of the malaria epidemic in the Peruvian Amazon, the reported age-specific attack rates were highest in adults, particularly males, suggesting that occupation is an important risk factor in this region ${ }^{4}$. 
Although in general, malaria infection was related to the age of the individual, only $P$. falciparum infection, showed a relationship with the age groups studied, when the analysis was performed using species specific infections. MARCANO et al. (2004) also found a higher malaria prevalence in individuals 10 years or younger in Yanomami communities from high Orinoco and Mucajaí basins ${ }^{22}$. There have been no reports so far showing that mosquitos prefer to bite children, inferring that both children and adults have the same probability being bitten by mosquitoes and thus becoming infected by Plasmodium spp. ${ }^{3}$. Malaria symptoms, however, are significantly more prevalent in younger age groups with asymptomatic infections being more common in older age groups, which agree with reports that relate the immune response to malaria infection in endemic areas, this being stronger with age and the number of episodes ${ }^{3,22,31}$.

It is interesting that most individuals in the populations studied stated that they had never been affected by malaria, even though they live in a high transmission area. Due to the frequency of asymptomatic infections, it is possible that many of these individuals were either infected with malaria but did not develop symptoms, or their immune systems protected them from infection.

On the other hand, LACROIX et al. (2005) inferred the possibility of intrinsic attraction mechanisms operating in children, since they found that a group of infected children with gametocytes were more attractive for the vector Anopheles gambiae ${ }^{19}$. Several factors, such as the age of the patient, the duration of infection prior to the collection of blood samples, previous exposure to the parasite and the intensity of the infection, could be related to this pattern. Among these factors, previous malaria infection is probably the most important ${ }^{38,42}$.

Even though presumptive malaria symptoms at the time of sampling were a good indication of infection, the asymptomatic malaria cases found in this study using PCR detection were of great epidemiological value, since these individuals represent the main malaria reservoirs in San Fernando de Atabapo and Santa Barbara. These asymptomatic malaria cases could represent a significant health problem due to their contribution to malaria transmission ${ }^{15}$. ROPER et al. (1996) suggested that asymptomatic individuals in the population possess some clinical protective immunity against parasite strains, demonstrating that this protective component is age-dependant ${ }^{31}$. It is thus necessary to determine the exact duration and clinical development of asymptomatic infections through longitudinal epidemiological studies ${ }^{23}$.

Knowledge regarding malaria infection by the inhabitants of these communities was empirical and related to the cause of the disease by mosquito bites. Knowledge about the symptoms of the infection and its treatment was only obtained after a malaria episode. It is interesting to note that none of the individuals from these populations knew how to prevent malaria. Although this is an endemic area for malaria, the inhabitants seem to be indifferent to the prevention of the disease, using very few measures to avoid mosquito bites, which have been reported as a risk behavior that favors the transmission of the disease ${ }^{17}$. The use of insecticides by government authorities in this area is periodical but insufficient. Also, no entomological studies have been carried out by government authorities in order to design better measures to prevent infection in the population. The effective rate of infected mosquitoes, detection of the different vector species present and the feeding behavior of those species could be used to design more effective control measures.

Most individuals, both children and adults, used mosquito nets frequently, showing a statistically significant negative association with $P$. vivax but not $P$. falciparum infection malaria. Thus the use of mosquito nets was shown to be a protective measure for $P$. vivax infection. RUBIO-PALIS (2003) and ALEXANDER et al. (2005) suggested that the effectiveness of the mosquito nets was limited for the control of malaria in an endemic area, especially when they have holes or are in contact with the skin of the individual ${ }^{2,34}$. In order to counteract this, insecticide-impregnated mosquito nets are recommended for malaria prevention due to their greater effectiveness $^{35,43}$.

Anopheles darlingi has been reported as the most efficient mosquito vector in the Amazon basin due to its susceptibility to Plasmodium infection ${ }^{27}$. Larvae develop in large water bodies, mainly dams, lakes, lagoons and the backwaters of large rivers, which are abundant in this area. This species is very anthropophagic, biting outside houses during peak hours, which could explain why mosquito nets did not protect against $P$. falciparum. The fact that mosquito nets do protect against $P$. vivax, suggests the possibility of the presence of more than one competent Anopheles species that transmits the Plasmodium species differentially. A second species that preferentially transmits $P$. vivax, preferring to bite inside the house, could explain the reduced number of cases in individuals using nets. The presence of more than one species of Anopheles acting as a vector in this area is also suggested by the differential distribution of malaria cases amongst the age groups for each of the Plasmodium species. If both species were being transmitted by a single mosquito vector, the pattern of distribution would be expected to be the same for a specific area, which was not the case in this study.

Although A. darlingi has been described as the main species in the Amazon basin in Bolivar State, Venezuela ${ }^{27}$, recent studies have demonstrated that there are more than one Anopheles species acting as malaria vectors in this region. MORENO et al. (2002) found that $A$. marajoara was more abundant (56.8\%) than A. darlingi $(38.2 \%)$, in a mining area of Bolivar State. This author pointed out that although both species bite both outside and inside the houses, the former showed a marked exophagic behavior ${ }^{25}$. A. marajoara was also reported to contribute to malaria transmission in the Meta basin, Colombia ${ }^{8}$.

Additionally, A. neomaculipalpus has been proven to be a new malaria vector in the Amazon region ${ }^{26}$, and A. nuneztovari, an important malaria vector in the southern slopes of the Andes in Venezuela, has also been reported from Bolivar State, Venezuela ${ }^{25,26}$. The differential capacity of transmitting Plasmodium species is related to entomological factors such as the susceptibility of the Anopheles species and their life cycle interaction, and with ecological factors that favor one vector species over another as well as their temporal and spatial distributions ${ }^{14,16,28,40}$.

We recommend the study of the Anopheles species present in the San Fernando de Atabapo and Santa Barbara regions to determine which of these could be potential malaria vectors. 
The detection of asymptomatic individuals is especially important not only for appropriate treatment, but also for a better understanding of the behavior and epidemiological relationships between the Plasmodium and Anopheles species. This relationship is a key factor in the design of effective control measures against malaria infection. In our case, the use of mosquito nets alone was not an effective measure to prevent infection due to the possible presence of a second, possibly exophagic, vector. Also, the treatment of malaria is dependent on the Plasmodium species, so it is critical to detect and treat each infection accordingly in order to avoid the emergence of resistant strains of Plasmodium.

\section{RESUMEN}

\section{Incidencia de malaria en una región endémica del estado Amazonas, Venezuela}

Este estudio fue llevado a cabo para determinar la incidencia de malaria en una región endémica del estado Amazonas, Venezuela. Doscientas muestras tomadas al azar fueron colectadas de individuos sintomáticos y asintomáticos de San Fernando de Atabapo y Santa Bárbara. Factores epidemiológicos fueron relacionados con la infección de malaria, diagnosticada por observación microscópica y por la amplificación por PCR de la secuencia del ADNr 18S. La prevalencia de malaria en estas poblaciones fue $28.5 \%$, en tanto que las prevalencias para $P$. vivax y $P$. falciparum fueron 12 y $17 \%$, respectivamente. No se encontró infección por $P$. malariae. Se encontró una infección mixta en un individuo asintomático. Los patrones de prevalencia difirieron entre los grupos de edades, dependiendo de la especie de Plasmodium. Se encontró una frecuencia de infecciones asintomáticas de $34.8 \%$ y $15.2 \%$ para $P$. vivax y $P$. falciparum, respectivamente. El uso de mosquiteros fue útil para prevenir infecciones por $P$. vivax, pero no protegió de infecciones por $P$. falciparum. Los resultados sugieren la presencia de mas de un mosquito vector en el área, mostrando patrones diferenciales de infección para cada especie de Plasmodium. Pareciera existir factores de riesgo asociados con la infección de malaria en algunos individuos. El estudio a nivel poblacional y el diagnóstico por PCR mejoró la exactitud del análisis estadístico en este estudio.

\section{ACKNOWLEDGEMENTS}

The authors would like to acknowledge the State Director of Health and Social Development of Amazonas State, Dr. Eujenio Torres, as well as the coordinator of the San Fernando de Atabapo Health Center, Dr. Yurbelys Flores, for their permission and support for the undertaking of this investigation. We would also like to acknowledge the assistance provided by Frances Osborn, who reviewed the manuscript to improve the English. We also want to thank all the individuals who participated in the study for their collaboration providing the samples and the information used. Finally, we would like to acknowledge the financial support of the Fondo Nacional de Ciencia, Tecnología e Innovación (FONACIT), Venezuela, project number PEM-2001001621.

\section{REFERENCES}

1. ACHÉ, A.; ESCORIHUELA, M.; PÁEZ, E. et al. - In vivo drug resistance of falciparum malaria in mining areas of Venezuela. Trop. Med. Int. HIth, 7: 737-743, 2002.
2. ALEXANDER, N.; RODRÍGUEZ, M.; PÉREZ, L. et al. - Case-control study of mosquito nets against malaria in the Amazon region of Colombia. Amer. J. trop. Med. Hyg., 73: $140-148,2005$.

3. ALVES, F.P.; DURLACHER, R.R.; MENEZES, M.J. et al. - High prevalence of asymptomatic Plasmodium vivax and Plasmodium falciparum infections in native Amazonian populations. Amer. J. trop. Med. Hyg., 66: 641-648, 2002.

4. ARAMBURÚ GUARDA, J.; RAMAl ASAYAG, C. \& WITZIG, R. - Malaria reemergence in the Peruvian Amazon region. Emerg. infect. Dis., 5: 209-215, 1999.

5. ASLAN, G.; ULUKANLIGIL, M.; SEYREK, A. \& OZCAN, E. - Diagnostic performance characteristics of rapid dipstick test for Plasmodium vivax malaria. Mem. Inst. Oswaldo Cruz, 95: 683-686, 2001.

6. BARKER Jr., R.H.; BANCHONGAKSORN, T.; COURVAL, J.M. et al. - A simple method to detect Plasmodium falciparum directly from blood samples using the polymerase chain reaction. Amer. J. trop. Med. Hyg., 46: 416-426, 1992.

7. BEAKER, J.; MULLER, R. \& ROLLISON, D. - Advances in Parasitology. Editorial. New York, Academic Press, 1996. v. 38.

8. BROCHERO, H.L.; REY, G.; BUITRAGO, L.S. \& OLANO V.A. - Biting activity and breeding sites of Anopheles species in the municipality Villavicencio, Meta, Colombia. J. Amer. Mosq. Control Ass., 21: 182-186, 2005.

9. CAMARGO, E.P.; ALVES, F. \& PEREIRA DA SILVA, L.H. - Symptomless Plasmodium vivax infections in native Amazonians. Lancet, 353: 1415-1416, 1999.

10. CAMARGO, L.M.; FERREIRA, M.; KRIEGER, H.; DE CAMARGO, E. \& DA SILVA, L.P. - Unstable hypoendemic malaria in Rondonia (Western Amazon region, Brazil): epidemic outbreaks and work-associated incidence in an agro-industrial rural settlement. Amer. J. trop. Med. Hyg., 51: 16-25, 1994.

11. CORDOVA, Y. \& RODRÍGUEZ, M. - Código de bioética y bioseguridad. 2. ed. Ministerio de Ciencia y Tecnología-Fondo Nacional de Ciencia, Tecnología e Innovación, 2003.

12. DIRECCION DE VIGILANCIA EPIDEMIOLOGICA. Ministerio de Salud y Desarrollo Social, Venezuela, 2004. Epidemiological Bulletin, year 54, epidemiological week 52, period from Dicember 26, 2004 to January 1, 2005 (downloadable at www.msds.gov.ve).

13. DIRECCION DE VIGILANCIA EPIDEMIOLOGICA. Ministerio de Salud y Desarrollo Social, Venezuela, 2005. Epidemiological Bulletin, year 55, epidemiological week 52, period from December 26 to December 31, 2005 (downloadable at www.msds.gov.ve).

14. GABALDON, A. - Malaria eradication in Venezuela: doctrine practice and achievements after twenty years. Amer. J. trop. Med. Hyg., 32: 203-211, 1983.

15. GREENWOOD, B.; MARSH, K. \& SNOW, R. - Why do some African children develop severe malaria? Parasit. today, 7: 277-281, 1991.

16. GU, W.; MBOGO, C.M.; GITHURE, J.I. et al. - Low recovery rates stabilize malaria endemicity in areas of low transmission in coastal Kenya. Acta trop., 86: 71-81, 2003 .

17. HII, J.; SMITH, T.; VOUNATSOU, P. et al. - Area effects of bednet use in a malaria endemic area in Papua New Guinea. Trans. roy. Soc. trop. Med. Hyg., 95: 7-13, 2001.

18. KAHN, H.A. \& TEMPOS, C.T. - Statistical methods in Epidemiology. New York, Oxford University Press, 1989.

19. LACROIX, R.; MUKABANA, W.R.; GOUAGNA, L.C. \& KOELLA, J.C. - Malaria infection increases attractiveness of humans to mosquitoes. PLoS Biol., 3: 298, 2005. 
20. LASERSON, K.F.; PETRALANDA, I.; HAMLIN, D.M. et al. - Use of the polymerase chain reaction to directly detect malaria parasites in blood samples from the Venezuelan Amazon. Amer. J. trop. Med. Hyg., 50: 169-180, 1994.

21. MAKLER, M.T.; PALMER, C.J. \& AGER, A.L. - A review of practical techniques for the diagnosis of malaria. Ann. trop. Med. Parasit., 92: 419-433, 1998.

22. MARCANO, T.J.; MORGADO, A.; TOSTA, C.E. \& COURA, J.R. - Cross-sectional study defines difference in malaria morbidity in two Yanomami communities on Amazonian boundary between Brazil and Venezuela. Mem. Inst. Oswaldo Cruz, 99: 369-376, 2004

23. MEHLOTRA, R.K.; LORRY, K.; KASTENS, W. et al. - Random distribution of mixed species malaria infections in Papua New Guinea. Amer. J. trop. Med. Hyg., 62: 225-231, 2002.

24. MILLER, L.; BARUCH, D.; MARSH, K. \& DOUMBO, O.K. - The pathogenic basis of malaria. Nature, 415: 673-679, 2002.

25. MORENO, J.E.; RUBIO-PALIS, Y.; PÉREZ, E.; SÁNCHEZ, V. \& PÁEZ, E. - Evaluación de tres métodos de captura de anofelinos en un área endémica de malaria del estado Bolívar, Venezuela. Entomotropica, 17: 157-165, 2002

26. MORENO, J.E.; RUBIO-PALIS, Y.; PÁEZ, E. et al. - Anopheles (Anopheles) neomaculipalpus: a new malaria vector in the Amazon basin? Med. vet. Entomol., 19: 329-332, 2005.

27. OSBORN, F.; RUBIO-PALIS, Y.; HERRERA, M.; FIGUERA, A. \& MORENO, J.E. Caracterización ecoregional de los vectores de malaria en Venezuela. Bol. Malariol. Salud amb., 44: 77-92, 2004.

28. PETERSEN, E.; HOGH, B.; DZIEGIEL, M. et al. - The antibody response to welldefined malaria antigens alter acute malaria in individuals living under continuous malaria transmisión. Acta trop., 51: 135-142, 1992.

29. POSTIGO, M.; MENDOZA, A. \& PÉREZ, H. - Malaria diagnosis by the polymerase chain reaction: a field study in south-eastern Venezuela. Trans. roy. Soc. trop. Med. Hyg., 92: 509-511, 1998

30. RODRÍGUEZ, S.; RUIZ, R. \& BOGGIANO, G. - Malaria por Plasmodium vivax: efectos del tratamiento sobre los niveles de inmunoglobulinas y variación de la expresión del antígeno CD23. Med. interna, 16: 118-127, 2000.

31. ROPER, C.; ELHASSAN, I.M.; HVIID, L. et al. - Detection of very low level Plasmodium falciparum infections using the nested polymerase chain reaction and a reassessment of the epidemiology of unstable malaria in Sudan. Amer. J. trop. Med. Hyg., 54: 325-331, 1996.
32. ROPER, M.H.; TORRES, R.S.; GOICOCHEA, C.G. et al. - The epidemiology of malaria in an epidemic area of the Peruvian Amazon. Amer. J. trop. Med. Hyg., 62: $247-$ 256,2000

33. ROSNER, B. - Fundamentals of biostatistics. 5. ed. Pacific Grove, Duxbury, 2000.

34. RUBIO-PALIS, Y. - Bioseguridad de mosquiteros tratados con insecticidas piretroides para la prevención y control de la malaria en Venezuela. Bol. Malariol. Salud amb. 43: 63,2003

35. RUBIO-PALIS, Y. \& GUERRA, L. - Evaluación del poder residual del insecticida Deltametrina en telas de mosquiteros. Entomotropica, 81: 63-68, 2003.

36. SA, D.R.; SOUSA-SANTOS, R.; ESCOBAR, A.L. \& COIMBRA Jr., C.E. - Malaria epidemiology in the Pakaanova (Wari') Indians, Brazilian Amazon. Bull. Soc. Path. exot., 98: 28-32, 2005 .

37. SACHS, J. \& MALANEY, P. - The economic and social burden of malaria. Nature, 415: 680-685, 2002.

38. SÁNCHEZ, E.; PÉREZ, H. \& MARTÍNEZ, C. - Malaria in the Amazon. Prevalence of Plasmodium falciparum antibodies in Amerindians inhabiting the Venezuelan Amazon. Ann. trop. Med. Parasit., 84: 307-312, 1990.

39. SNOUNOU, G.; VIRIYAKOSOL, S.; JARRA, W.; THATHONG, S. \& BROWN, N. Identification of the four human malaria parasites species in field samples by the polymerase chain reaction and detection of a high prevalence of mixed infections. Molec. Biochem. Parasit., 58: 283-292, 1993.

40. SNOW, R.W. \& MARS, K. - The consequences of reducing transmission of Plasmodium falciparum in Africa. Advanc. Parasit., 52: 235-264, 2002.

41. THOMPSON, M.L.; MYERS, J.E. \& KRIEBEL, D. - Prevalence odds ratio or prevalence ratio in the analysis of cross sectional data: what is to be done? Occup. environ. Med., 55: 272-277, 1998.

42. WHITE, N.J. - Antimalarial drug resistance (review). J. clin. Invest., 113: 1084-1092, 2004.

43. ZIMMERMAN. R. \& VOORHAM, J. - Uso de mosquiteros y otros materiales impregnados con insecticidas para el control de la malaria en las Americas. Rev. panamer. Salud publ., 2: 18-25, 1997.

Received: 2 June 2006

Accepted: 29 August 2006 